\title{
Sistem Informasi Rumah Kontrakan Di Kecamatan Syiah Kuala Berbasis Web GIS
}

\author{
Juanda Saputra, Raihan Islamadina, Said Mustafa \\ Program Studi Teknik Komputer - Universitas Serambi Mekkah \\ Email: juandasp42@gmail.com
}

\begin{abstract}
Abstrak - Teknologi informasi sekarang merupakan kebutuhan dalam melakukan berbagai kegiatan, dengan menggunakan teknologi informasi yang sesuai, maka akan menghasilkan sebuah data yang berbentuk informasi yang sesuai dengan kebutuhan sehingga dapat mengambil keputusan dengan cepat dan akurat. Rumah kontrakan merupakan rumah yang dibangun sebagai rumah tinggal dan dipakai atau di manfaatkan dengan uang penyewaan dimana didalamnya ada persetujuan dari satu pihak. Aplikasi ini bertujuan sistem informasi rumah kontrakan yang mampu memberikan informasi mengenai rumah kontrakan sesusai dengan kiteria yang akan dihuni. Dengan adanya sistem informasi rumah kontrakan dikecamatan syiah kuala mempermudah bagi mahasiswa ataupun bagi pencari rumah kontrakan yang ada di kecamatan syiah kuala. Aplikasi ini dirancang menggunakan metode "waterfall" dengan tahapan perancangan sistem, desain sistem, penulisan koding, pengujian sistem dan pemeliharaan. Sistem informasi rumah kontrakan dikecamatan syiah kuala dapat mengelola dan menghasilkan data rumah kontrakan dengan lengkap dan detail.
\end{abstract}

Kata Kunci: Teknologi informasi, Informasi, Rumah kontrakan

\begin{abstract}
Information technology is a necessity in carrying out various activities, by using appropriate information technology, it will produce data in the form of information according to needs so that it can make decisions quickly and accurately. A rented house is a house that is built as a residence and is used or used with money in which there is an agreement from one party. This application aims to be a rented house information system that is able to provide information about rented houses in accordance with the criteria that will occur. With the information system for rented houses in the district of Syiah Kuala, it is easier for students or for seekers of rented houses in the district of Syiah Kuala. This application is designed using the "waterfall" method with the stages of system design, system design, coding writing, system testing, and maintenance. The information system for rented houses in the district of Syiah Kuala can manage and produce complete and detailed data on rented houses.
\end{abstract}

Keywords: Information technology, Information, Rented house

\section{Pendahuluan}

Geographic Information System (GIS) adalah teknologi berbasis komputer yang sengaja dibangun untuk mengumpulkan, menyimpan, mengolah, menganalisa dan menyajikan data informasi dari objek atau fenomena yang dimana berkaitan dengan tata letak atau keadaan yang ada di permukaan bumi tujuan nya adalah untuk membantu masyarakat mencari tempat lokasi yang sedang dicari[1].

Teknologi informasi saat ini adalah kebutuhan manusia di dalam melakukan berbagai kegiatan, dengan adanya piranti teknologi informasi yang tepat, maka dapat menghasilkan sebuah informasi yang sesuai dengan keperluan sehingga yang diputuskan dapat diambil dengan cepat[2]. Pengguna sistem informasi dalam bisnis atau tempat kerja sangatlah dibutuhkan untuk perkembangan, penukaran informasi secara elektronik ke dalam aplikasi strategi bisnis, seperti: penjualan dan pelayanan kepada pelanggan, begitu juga dalam hal bidang properti untuk rumah kontrakan. Perkembangan sistem informasi semakin cepat bisa dimanfaatkan dengan baik, namun masih ada banyak pengelola rumah kontrakan dan juga banyak calon penyewa usaha rumah kontrakan masih mengalami banyak kesusahan dalam memiliki suatu sistem yang terintegrasi.

Sistem informasi rumah kontrakan yang dapat penyedia informasi yang lengkap mengenai rumah kontrakan maka mahasiswa tidak perlu lagi menghabiskan banyak waktu untuk mendatangi tempat kontrakan satu persatu untuk mencari rumah kontrakan yang masih kosong. Dengan adanya Jasa sistem informasi kontrkan ini sangat bermanfaat untuk keefektifan dan keefisienan waktu.

Tujuan utama website ini adalah untuk memberikan kemudahan dalam setiap aktivitas bagi mahasiswa dan pemilik rumah kontrakan[3]. Mahasiswa lebih mudah mencari rumah kontrakan dan pemilik kontrakan juga akan merasakan kemudahana dalam website ini. Diharapkan dengan adanya website ini memberikan keefektifan buat pengguna dan menjadi salah satu contoh untuk pengembang aplikasi web lainnya. Aplikasi web ini dibuatkan berdasarkan data dari kebutuhan mahasiswa terhadap permasalahan mencari rumah kontrakan di daerah Kecamatan Syiah Kuala, karena belum adanya pengolahan data sistem informasi rumah kontrakan.

Dengan latar belakang diatas penulis ingin membuatkan web sistem informasi rumah kontrakan, maka dari itu penulis berinisiatif dan sangat tertarik sekali mengambil judul tentang "Sistem Informasi Rumah Kontrakan di Kecamatan Syiah Kuala Berbasis Web GIS". 
Agar penyusunan proposal ini menjadi tidak menyimpang dari permasalahan yang ada, maka penulis membatasi pokok permasalahan yaitu, bagaimana merancang Sistem Informasi Rumah Kontrakan di Kecamatan Syiah Kuala Berbasis Web GIS.

Adapun rumusan masalahnya sebagai berikut:

a. Bagaimana cara membangun web Sistem Informasi Rumah Kontrakan di Kecamatan Syiah Kuala Berbasis Web GIS.

b. Bagaimana mengaplikasikan Sistem Informasi Rumah Kontrakan di Kecamatan Syiah Kuala Berbasis Web GIS.

Adapun tujuan penulis dalam proposal dalam membuat Sistem Informasi Rumah Kontrakan di Kecamatan Syiah Kuala Berbasis Web GIS adalah:

a. Membuat sistem informasi rumah kontrakan yang mampu memberikan informasi mengenai rumah kontrakan sesuai dengan kiteria yang akan dihuni.

b. Membuat sistem yang dapat memunculkan map dengan API Maps Google untuk mengetahui lokasi mengenai rumah kontrakan

Diharapkan dengan adanya Sistem Informasi Rumah Kontrakan di Kecamatan Syiah Kuala:

a. Mempermudah bagi Mahasiswa ataupun bagi pencarian rumah kontakan yang ada di Kecamatan Syiah Kuala.

b. Menumbuhkan pekerbangan pemanfaatan teknologi secara optimal bagi kalangan penyedia kontrakan sehingga bagi yang mencari kontrakan akan lebih mudah.

c. Memenuhi syarat tugas akhir penulis dalam menyelesaikan perkuliahan.

\section{Tinjauan Pustaka}

\subsection{Sistem}

Sistem merupakan jaringan prosedur yang terpadu untuk kegiatan pokok perusahaan[4]. Sebuah sistem adalah input, proses, dan output. Hal ini merupakan konsep sistem yang senferhana dikarenakan sistem dapat mempunyai beberapa masukan seerta pengeluaran. Berdasarkan pendapat para ahli, penulis dapat menyimpulkan sistem adalah serangkaian dua atau lebih komponen yang saling berinteraksi untuk mencapai suatu tujuan[5].

\subsection{Informasi}

Informasi merupakan sebuah data yang telah dikelola atau klasifikasi dan menjadi suatu bentuk penting bagi pihak penerima informasi dan juga mempunyai nilai yang dapat dirasakan dalam keputusan yang dimasa sekarang ataupun keputusan yang datang suatu hari nanti[6]. Informasi merupakan data yang telah diklasifikasi atau telah dikelola yang digunakan dalam proses pengambilan keputusan, sistem informasi mengolah data menjadi sebuah informasi atau tepatnya pengolah data dari betuk tak berguna menjadi berguna bagi penerima informasi tersebut[1]. Berdasarkan pendapat para ahli, penulis dapat menyimpulkan informasi adalah sebuah data yang telah diproses dan pemakai dapat melakukan tindakan dimana dia melakukan atau tidak melakukan setelah mendapatkan informasi tersebut.

\subsection{Sistem Informasi}

Sistem Informasi merupakan pengolahan data yang mendukung fungsi proses organisasi yang bersifat perpaduan seni dan ilmu dengan kegiatan-kegiatan strategi organisasi untuk dapat menyediakan kepada pihak luar tertentu dengan laporan yang diperlukan[7]. Sistem informasi yaitu suatu sistem yang menyediakan sebuah informasi untuk manajemen dalam mengambil keputusan dan juga untuk menjalankan perusahaan, dimana sistem tersebut merupakan kombinasi dari banyak orang, teknologi informasi dan prosedur-prosedur yang terorganisasi[8]. Berdasarkan pendapat para ahli, penulis dapat menyimpulkan Sistem informasi adalah kumpulan hardware dan software, maupun database yang mengumpulkan data lalu data tersebut mengubah dan menyebarkan informasi dalam bentuk sekolompok.

\subsection{Rumah Kontrakan}

Rumah kontrakan adalah sebuah bangunan yang berfungsi sebagai tempat tinggal yang dapat dipakai atau di manfaatkan dengan membayar uang sewa dimana di dalamnya perlu persetujuan dahulu antara pihak pemilik dengan pihak penyewa yang dimana pihak yang pemilik tadi menyerahkan semuah yang ada di rumah tersebut kepada pihak penyewa untuk dinikmati sepenuhnya[9].

\subsection{Pengerian Data}

Data merupakan bahan yang masih mentah untuk di olah setelah diolah akan menghasilkan lalu kemudian menjadi sebuah informasi yang bermanfaat. Data yang telah diperoleh harus dinilaikan dulu baik buruknya, berguna atau tidak dalam hubungannya dengan tujuan[10]. Data merupakan istilah majemuk yang berarti nyata adanya atau bagian dari fakta, simbol, gambar, angka, yang menunjukkan suatu ide, objek, kondisi, atau situasi[11]. Berdasarkan pendapat para ahli, penulis dapat menyimpulkan data merupakan kenyataan tempat dan kenyataan, Sekumpulan data dapat diolah menjadi informasi yang berguna.

\subsection{GIS (Geography Information System)}


GIS merupakan sebuah komputer yang berbasis sistem informasi digunakan untuk memberikan informasi bentuk digital dan analisis terhadap permukaan geogra bumi[12]. GIS merupakan sebuah system yang digunakan untuk menginput, menyimpan, memanggil kembali, menganalisis, dan memvisualisasikan data atau informasi spasial[13]. Berdasarkan pendapat para ahli, penulis dapat menyimpulkan GIS adalah sebuah sistem atau teknologi berbasis komputer yang dibangun dengan tujuan untuk mengumpulkan, menyimpan, mengolah, dan menganalisa, serta menyajukan data dan informasi dari suatu obyek atau fenomena yang berkaitan dengan letak atau keberadaannya di permukaan bumi.

\section{Metodelogi Penelitian}

\subsection{Objek dan Alur Penelitian}

Objek yang dikaji pada penelitian ini adalah Data Kontrakan Yang Ada di Kecamatan Syiah Kuala.

Penulis Menggunakan Konsep Standar Metode yang digunakan oleh para developer web, yaitu metode "Waterfall" Tahapan penilitian Sistem informasi Rumah Kontrakan yaitu Metode Waterfall dengan tahapan penelitian berikut ini :

\section{Perancangan Sistem}

Perencangan bermula dari perancangan sistem yang dibangun, merancang database, table, merancang bagaimana flowchart yang dibangun atau alur sistemnya, membuat peta situs, membuat jadwal kerja, mengumpulkan bahan dan hal lain yang diperlukan. Perancangan sistem merupkana penentuan dari proses data yang diperlukan oleh sistem baru, tujuan dari perancangan sistem merupakan untuk dapat memenuhi kebutuhan pengguna sistem serta untuk memberikan gambaran yang jelas.

\section{Desain Sistem}

Setelah menyelesaikan rancangan sistem dan telah diterima. Tahapan selanjutnya adalah merancang design seperti warna, konsep web, font huruf, filosofi, dan sebagainya.

3. Penulisan Koding

Tahap ini merupakan tahap proses yang paling lama memakan waktu dan sulit. Karena tahapan ini berisi coding-coding untuk membangun program dengan sistem dan design yang telah direncanakan.

4. Pengujian Sistem

Setelah menyelesaikan penulisan koding program harus dilakukan uji coba terlebih dahulu untuk mengetahui kesalahan atau adanya sistem yang tidak dapat dijalankan dalam program yang dibangun.

5. Pemeliharaan Web

Setelah Web Program berhasil berjalan dan telah digunakan harus dilakukan pemeliharaan jika dalam penggunaan sistem mengalami kerusakan atau ada fitur yang ingin ditambahkan.

\subsection{Bagan Alir Dokumen Flowmap Sistem yang Diusulkan}

Bagan alir system usulan diperlihatkan pada gambar 1 dibawah ini :

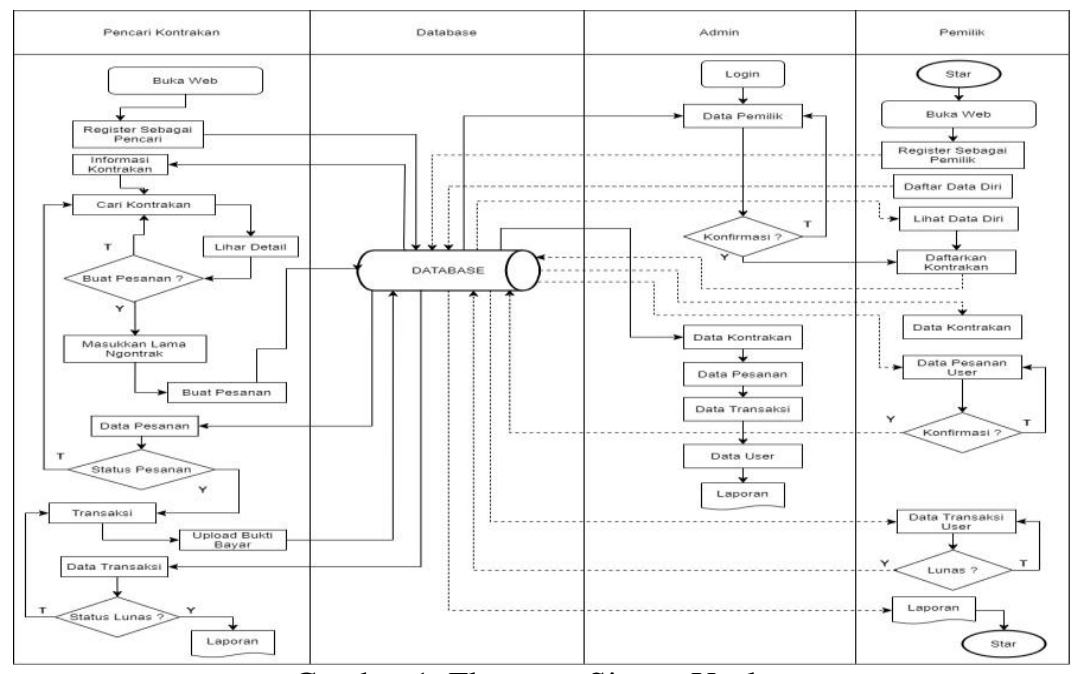

Gambar 1. Flowmap Sistem Usulan

\subsection{Rancangan Sistem}

Rancangan analisa ada beberapa tahap yang akan dirancang adalah flowmap berjalan, flowmap usulan, Data Flow Diagram (DFD), Diagram Konteks, Entry Relationship Diagram (ERD) dan Implementasi hasil rancangan dengan PHP MySql. Rancangan sistem merupakan penentuan dari proses data yang diperlukan oleh sistem baru, apabila sistem tersebut berbasis komputer, maka rancangan dapat ikut spesifikasi jenis peralatan 
yang digunakan. Rancangan sistem secara umum merupakan memberikan gambaran sistem secara umum kepada pengguna tentang sistem yang baru dirancang. Desain sistem secara umum mengetahui komponenkomponen sistem informasi yang didesain secara rinci.

\subsection{Diagram Konteks}

Pada Gambar 2 di bawah ini, menggambarkan secara umum aliran dari mana data yang masuk ke sistem dan data yang dihasilkan dari system.

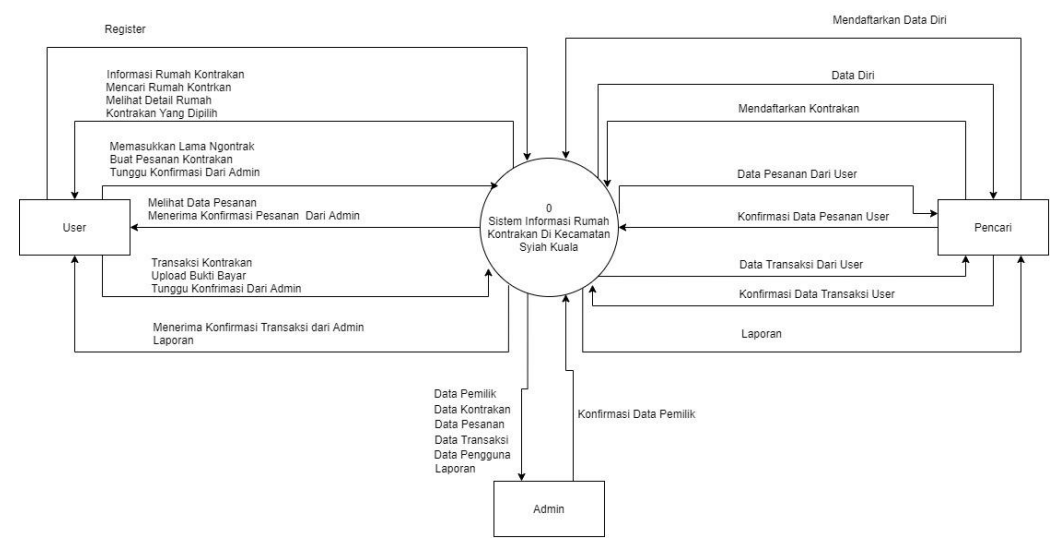

Gambar 2. Diagram Konteks

\subsection{Data Flow Diagram (DFD) Level 1}

Pada DFD Level 1 menjelaskan bagaimana pelanggan memesan kontrakan seperti yang terlihat pada gambar 3.

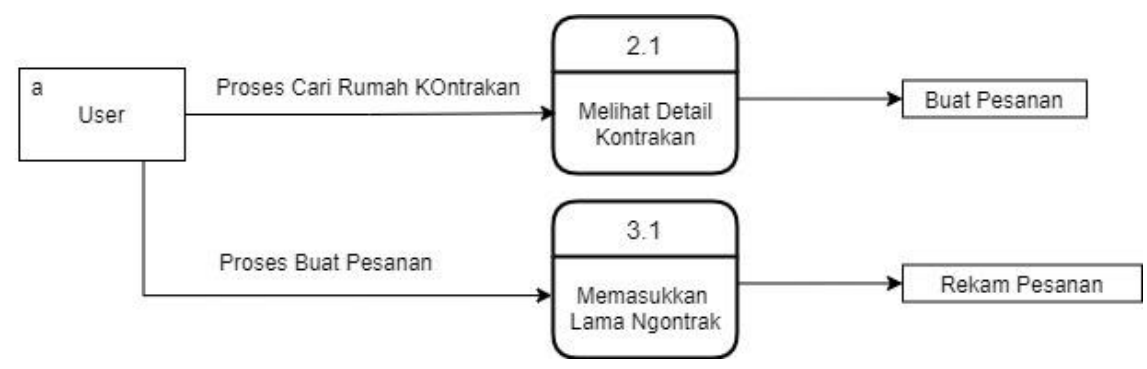

Gambar 3. Data Flow Diagram (DFD) Level 1

\subsection{Data Flow Diagram (DFD) Level 2}

Pada DFD Level 2 menjelaskan bagaimana pemilik data membuka kontrakan setelah melakukan daftar akun seperti yang terlihat pada gambar 4 .

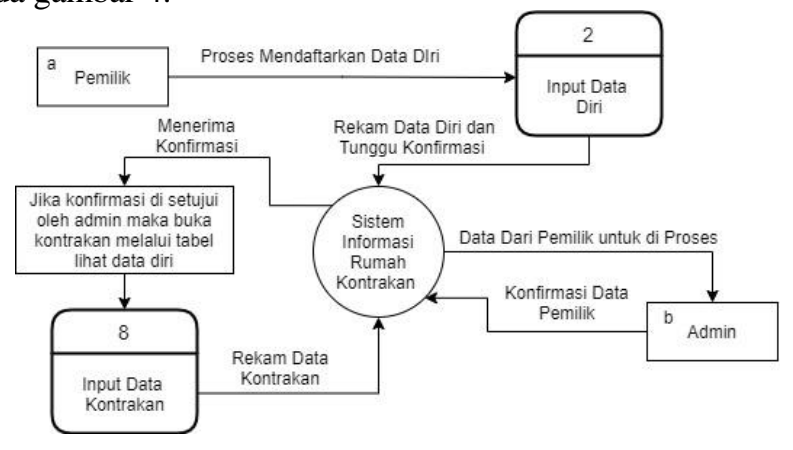

Gambar 4. Data Flow Diagram (DFD) Level 2.

\subsection{Struktur Database}

Adapun struktur tabel yang diperoleh dari hasil merelasikan entitas-entitas yang terlihat dalam suatu sistem informasi rumah kontrakan di Kecamatan Syiah Kuala adalah sebagai berikut: 
1. Tabel User

Nama : user

Primary Key : : id

Tabel 1. Tabel User

\begin{tabular}{|c|c|c|c|c|c|}
\hline No. & Nama & Jenis & Ukuran & Keterangan & Kunci \\
\hline 1 & Id & INT & 11 & Kode User & PK \\
\hline 2 & Nama_User & Varchar & 20 & Nama Pengguna & \\
\hline 3 & Nohp & Varchar & 20 & Untuk Login & \\
\hline 4 & Password & Varchar & 20 & Password & \\
\hline 5 & Alamat & Varchar & 50 & Alamat & \\
\hline 6 & Jenis_Kelamin & Vachar & 20 & Jenis Kelamin & \\
\hline 7 & Foto & Varchar & 100 & Foto Profil & \\
\hline 8 & Level & Varchar & 20 & Level Akun & \\
\hline
\end{tabular}

2. Tabel Data Pemlilik

Nama : data_pemlik

Primary Key : id_data

Foreign Key : id

Tabel 2. Tabel Data Pemilik

\begin{tabular}{|c|c|c|c|c|c|}
\hline No. & Nama & Jenis & Ukuran & Keterangan & Kunci \\
\hline 1 & Id_Data & INT & 11 & Kode Pemilik & PK \\
\hline 2 & Id & INT & 11 & Kode User & FK \\
\hline 3 & No_Ktp & Varchar & 20 & No KTP & \\
\hline 4 & Nohp_Pemilik & Varchar & 20 & No HP Pemilik & \\
\hline 5 & Nama_Pemillik & Varchar & 30 & Nama Pemilik & \\
\hline 6 & Jenis_Kelamin & Varchar & 50 & Jenis Kelamin & \\
\hline 7 & Alamat & Varchar & 100 & Alamat Pemilik & \\
\hline 8 & No_Rakening & Varchar & 20 & No Rakening & \\
\hline 9 & Nama_bank & Varchar & 30 & Nama Bank & \\
\hline 10 & Email & Varchar & 20 & Email Pemilik & \\
\hline 11 & Gambar1 & Vachar & 200 & Gambar Pemilik & \\
\hline 12 & Status_data_pemilik & Varchar & 20 & Status data pemilik & \\
\hline
\end{tabular}

3. Tabel Data Kontrakan

Nama : data_kontrakan

Primary Key : id_kontrakan

Foreign Key : id_data

Foreign Key : id

Tabel 3. Tabel Data Kontrakan

\begin{tabular}{|c|c|c|c|c|c|}
\hline No. & Nama & Jenis & Ukuran & Keterangan & Kunci \\
\hline 1 & id_transaksi & INT & 11 & Kode transaksi & PK \\
\hline 2 & id & INT & 11 & Kode user & FK \\
\hline 3 & id_pesan & INT & 11 & Kode pesan & FK \\
\hline 4 & Id_kontrakan & Varchar & 20 & Kode kontrakan & FK \\
\hline 5 & bukti_bayar & Varchar & 200 & Gambar bukti bayar & \\
\hline 6 & tanggal_transaksi & Date & - & Tanggal transaksi & \\
\hline 7 & tanggal_mulai & Date & - & Tanggal mulai singgah & \\
\hline 8 & Tanggal_akhir & Date & & Tanggal akhir sewa & \\
\hline 9 & Banyak_hari & Varchar & 20 & Banyak hari sewa & \\
\hline 10 & Status & Vachar & 20 & Status konfirmasi & \\
\hline
\end{tabular}


4. Tabel Data Pesanan

Nama : pesanan

Primary Key : id_pesan

Foreign Key : id

Foreign Key : id_kontrakan

Tabel 4. Tabel Data Pesanan

\begin{tabular}{|l|c|c|c|c|c|}
\hline No & Nama & Jenis & Ukuran & Keterangan & Kunci \\
\hline 1 & Id_Kontrakan & INT & 11 & Kode Kontrakan & PK \\
\hline 2 & Id_Data & INT & 11 & Kode Pemilik & FK \\
\hline 3 & Id & INT & 11 & Kode User & FK \\
\hline 4 & Type & Varchar & 20 & Type Sewa & \\
\hline 5 & Kategori & Varchar & 20 & Kategori Sewa & \\
\hline 6 & Jumlah_Kamar & Varchar & 20 & Jumlah Kamar & \\
\hline 7 & Luas & Varchar & 20 & Luas Kontrakan & \\
\hline 8 & Alamat_Kontrakan & Varchar & 200 & Alamat Kontrakan & \\
\hline 9 & Latitude & Varchar & 50 & Latitude & \\
\hline 10 & Longtitude & Varchar & 50 & Longtitude & \\
\hline 11 & Harga_Bulan & Varchar & 20 & Harga Bulan & \\
\hline 12 & Keterangan & Text & - & Keterangan & \\
\hline 13 & Gambar1 & Varchar & 100 & Gambar Pilihan 1 & \\
\hline 14 & Gambar2 & Varchar & 100 & Gambar Pilihan 2 & \\
\hline 15 & Gambar3 & Varchar & 100 & Gambar Pilihan 3 & \\
\hline 16 & Status_kontrakan & Varchar & 20 & Status Kontrakan & \\
\hline
\end{tabular}

5. Tabel Data Transaksi

Nama : transaksi

Primary Key : id_transaksi

Foreign Key : id

Foreign Key : id_pesan

Foreign Key : id_kontrakan

Tabel 5. Tabel Data Transaksi

\begin{tabular}{|c|c|c|c|c|c|}
\hline No. & Nama & Jenis & Ukuran & Keterangan & Kunci \\
\hline 1 & Id_Pesan & INT & 11 & Kode Pesan & PK \\
\hline 2 & Id & INT & 11 & Kode User & FK \\
\hline 3 & Id_Kontrakan & INT & 11 & Kode Kontrakan & FK \\
\hline 4 & Bulan & Varchar & 20 & Lama Ngontrak & \\
\hline 5 & Total_Bayar & Varchar & 20 & Total Bayar & \\
\hline 6 & Tanggal_Pesan & Date & - & Tanggal Pesan & \\
\hline 7 & Tanggal_Tempo & Date & - & Tanggal Akhir Bayar & \\
\hline 8 & Status & Vachar & 20 & Status Konfirmasi & \\
\hline
\end{tabular}

\section{Hasil Dan Pembahasan}

Sistem Informasi Rumah Kontrakan di Kecamatan Syiah Kuala Berbasis Web GIS yang telah dibangun ini dijelaskan dengan pembahasan secara umumnya yaitu mulai halaman form input dan hasil laporan dari sistem.

\subsection{Halaman Sign Up}

Halaman sign up merupakan halaman untuk mendaftarkan diri jika belum ada akun untuk login maka diwajibkan daftar dan memilih daftar sebagai pencari atau pemilik. Halaman sing up terdapat inputan nama, no hp, password, jenis kelamin, daftar sebagai apa dan foto profil. Halaman sing up dapat dilihat pada gambar 5. Setelah sign up maka dialihkan ke halaman login. 


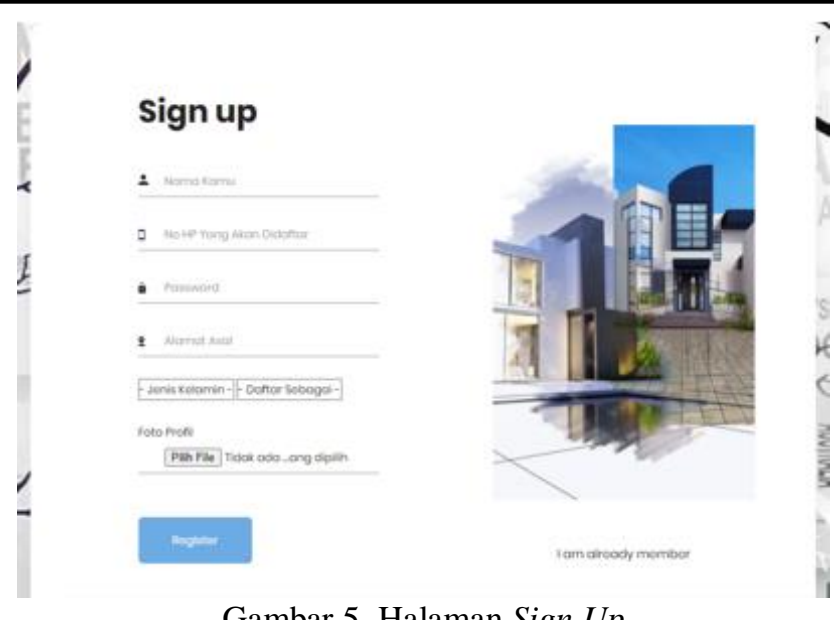

Gambar 5. Halaman Sign Up

\subsection{Halaman Login}

Halaman Login adalah halaman hasil dari sign up, jika tidak melakukan login maka user tidak dapat membuat pesanan atau medaftarkan kontrakan. Halaman login terdapat inputan no hp dan password. Setelah login maka di alihkan ke halaman menu utama / beranda. Halaman login dapat dilihat pada gambar 6.

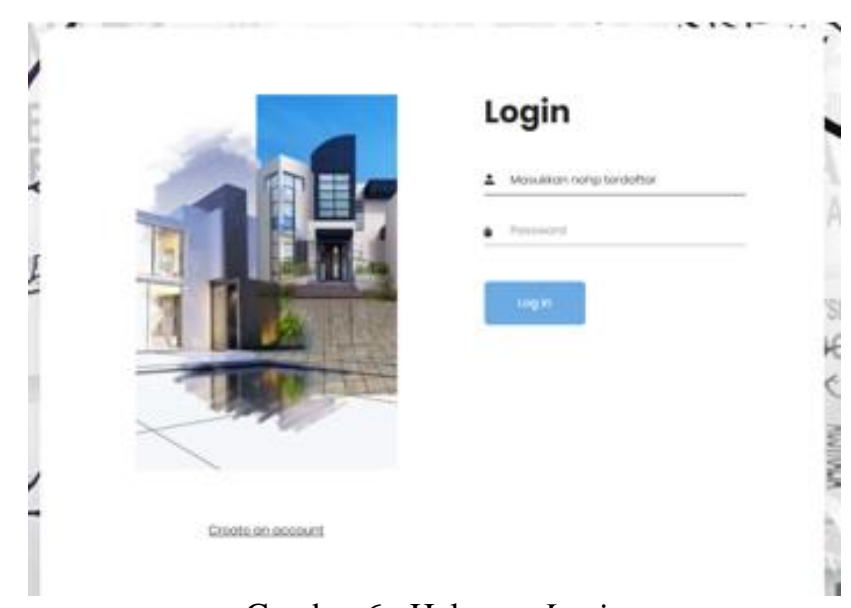

Gambar 6. Halaman Login

\subsection{Halaman Menu Utama / Beranda}

Menu utama merupakan halaman ketika berhasil login. Halaman Menu utama terdapat data kontrakan yang dapat pesan setelah berhasil login, jika tidak login maka tidak bisa membuat pesanan dan untuk pemilik tidak dapat membuat pesanan. Halaman Menu Utama / Beranda dapat dilihat pada Gambar 7.

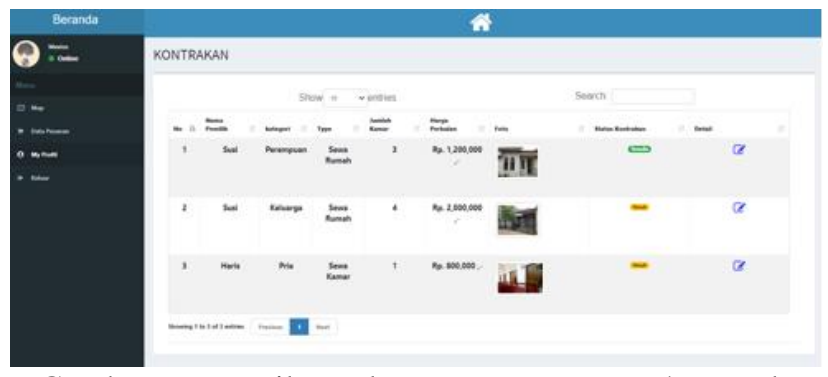

Gambar 7. TampilanHalaman Menu Utama / Beranda

\subsection{Halaman Daftarkan Data Pemilik}

Halaman daftar pemilik merupakan untuk mendaftakan data pemilik baru, halaman ini hanya dapat di akses oleh pemilik. Halaman daftrakan data pemilik terdapat inputan no ktp, no hp pemilik, nama pemilik, jeni kelamin, alamat pemilik, nama bank, no rakening, email pemilik dan foto pemilik. Tampilan halaman ini dapat dilihat pada gambar 8 . 


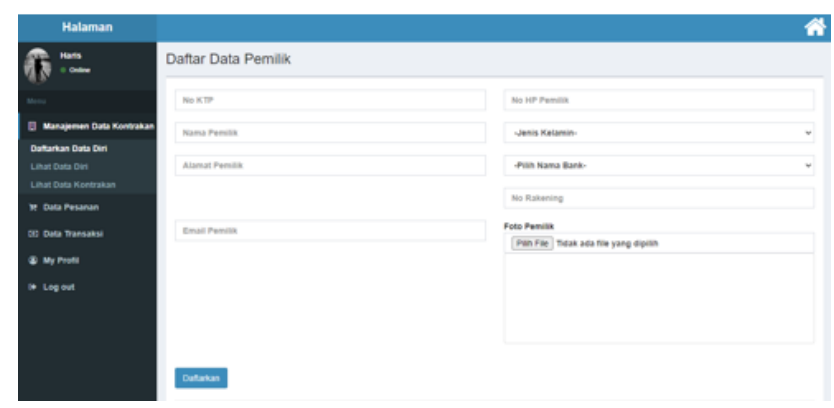

Gambar 8. Tampilan Halaman Daftarkan Pemilik

\subsection{Halaman Lihat Data Pemilik}

Halaman lihat data pemilik merupakan tampilan hasil data setelah melakukan mendaftarkan daftar pemilik oleh pemilik. Halaman lihat data diri juga merupakan halaman untuk mebuka kontrakan melalui tambahkan kontrakan dengan tombol warna hijau. Tampilan halaman ini, dapat dilihat pada gambar 9. Halaman lihat data pemilik yang di admin merupakan untuk konfirmasi data pemilik setelah pemilik mendaftarkan data, dapat dilihat pada gambar 10.

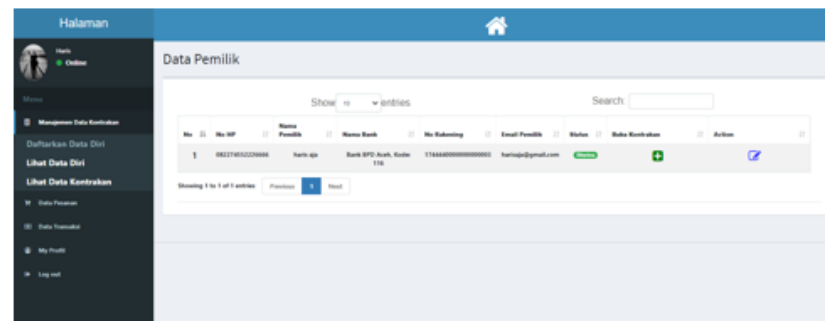

Gambar 9. Tampilan Hasil Data Pemilik Dari Pemilik

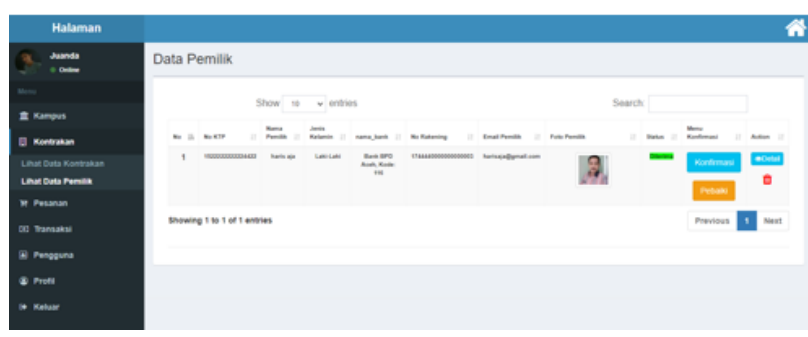

Gambar 10. Tampilan Hasil Data Pemilik Dari Admin

\subsection{Halaman Daftarkan Kontrakan}

Halaman daftar kontrakan merupakan untuk mebuka kontrakan baru, halaman ini hanya dapat diakses oleh pemilik melalui lihat data pemilik dari pemilik. Halaman daftarkan kontrakan terdapat inputan kategori sewa, type sewa, alamat kontrakan bentuk map, jumlah kamar, luas permeter, harga perbulan, keterangan dari pemilik, gambar utama, gambar pilihan 1 dan gambar pilihan 2. Tampilan halaman ini dapat dilihat pada gambar 11.
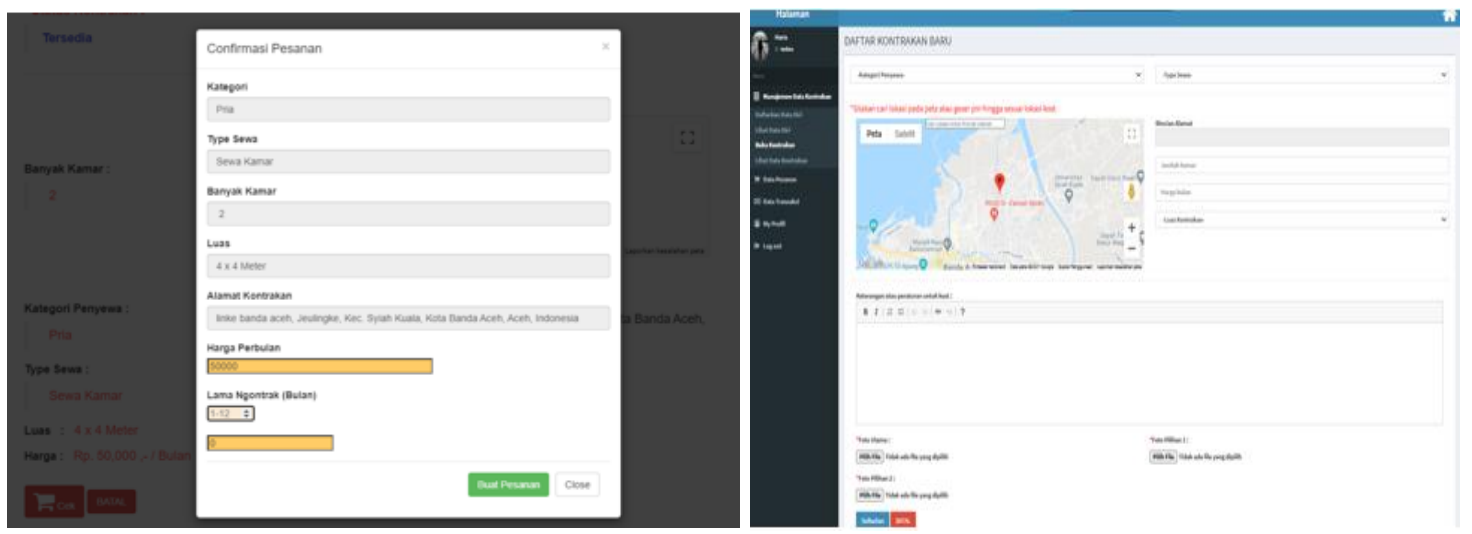

Gambar 11. Tampilan Halaman Daftarkan Kontrakan 


\subsection{Halaman Lihat Data Kontrakan}

Halaman lihat data kontrakan merupakan hasil data kontrakan yang sudah di daftarkan oleh pemilik. Halaman lihat data kontrakan yang sudah di daftarkan pencari dapat melihat di halaman menu utama / beranda. Tampilan halaman ini dapat dilihat pada gambar 12.

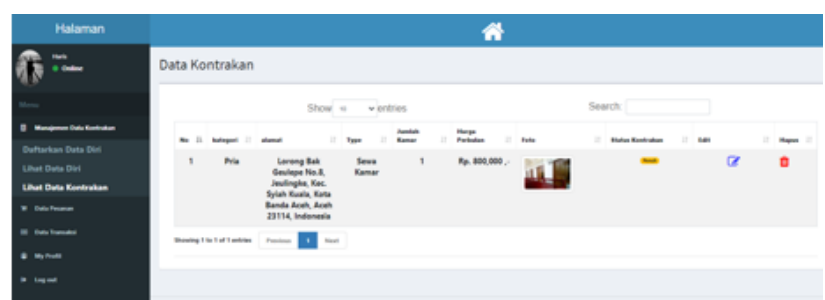

Gambar 13. Tampilan Halaman Lihat Data Kontrakan

\subsection{Halaman Buat Pesanan}

Halaman buat pesana merupakan halaman untuk memesan kontrakan, pencari dapat membuat pesanan setelah memasukkan lama ngontrak dan menekan tombol buat pesanan warna hijau. Pencari hanya dapat memesan satu kontrakan, tampilan halaman ini dapat dilihat pada gambar 14.

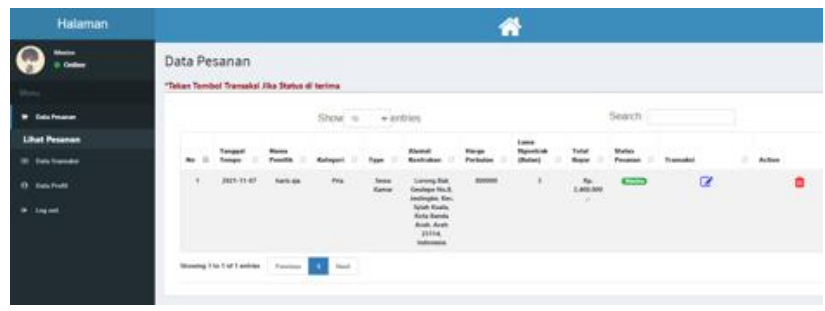

Gambar 14. Tampilan Buat Pesanan

\subsection{Halaman Data Pesanan}

Halaman data pesanan merupakan halaman melihat data pesanan yang telah dipesan oleh pencari, setelah pencari membuat pesanan pencari menunggu konfirmasi oleh pemilik, setelah status diterima maka pencari bisa melakukan transaksi kontrakan yang sudah dipesan. Halmaan ini dapat dilihat pada gambar 15.

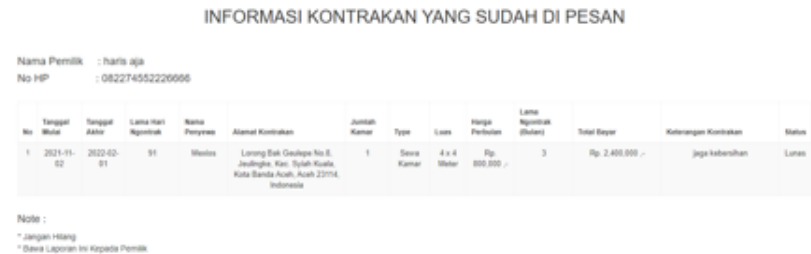

Gambar 15. Tampilan Halaman Data Pesanan

\subsection{Halaman Transaksi Kontrakan}

Halaman transaksi kontrakan adalah halaman untuk mentransaksikan pesanan yang sudah di konfirmasi oleh pemilik dan pencari diwajibkan mengupload gambar bukti transfer ke no rakening yang terdapat di halaman. Pencari hanya dapat transaksi satu kontrakan, halaman ini dapat dilihat pada gambar 16.

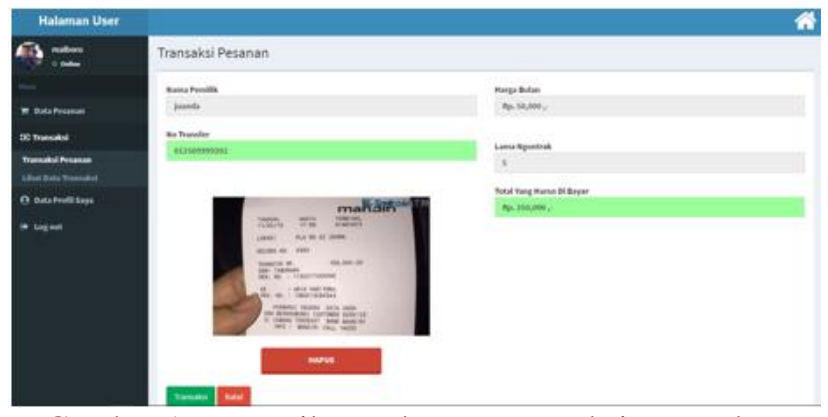

Gambar 16. Tampilan Halaman Transaksi Kontrakan 


\subsection{Halaman Data Transaksi}

Halaman data transaksi adalah halaman hasil transaksi kontrakan yang sudah ditransaksi, jika status transaksi lunas maka pencari harus mengambil laporan untuk sebagai bukti penyewaan kontrakan. Halaman ini dapat dilihat pada gambar 17.

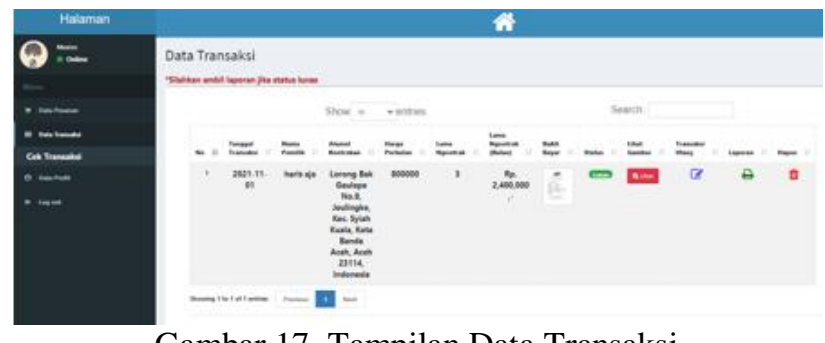

Gambar 17. Tampilan Data Transaksi

\subsection{Halaman Tampilan GIS}

Halaman tampilan GIS adalah tampilan data kontrakan yang telah di daftarkan oleh admin yang ditampilkan dalam bentuk map. Halaman ini dapat dilihat pada gambar 18.

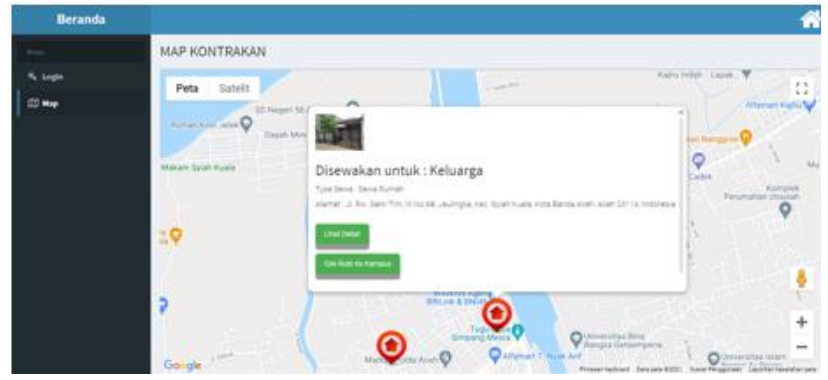

Gambar 18. Tampilan GIS

\section{Kesimpulan}

Berdasarkan tujuan penelitian maka kesimpulan dari hasil penelitian ini adalah:

1. Sistem Informasi Rumah Kontrakan di Kecamatan Syiah Kuala dapat di bangun dan berjalan dengan baik bedasarkan masukkan data.

2. Sistem Informasi Rumah Kontrakan di Kecamatan Syiah Kuala dapat mengelola dan menghasilkan data rumah kontrakan dengan lengkap dan detail.

\section{Daftar Pustaka}

[1] D. Satria, S. Yana, E. Yusibani, and S. Syahreza, "Zulfan, 'Implementation of the SMS gateway in the flood early warning information system for village warning and community information," Int. J. Eng. Adv. Technol, vol. 8, no. 6, pp. 4005-4009, 2019.

[2] M. Munawir, Z. Zainal, T. Hidayat, and S. Susmanto, "Perancangan Aplikasi e-discussion untuk Dosen Fakultas Teknik Universitas Serambi Mekkah,” J. Nas. Komputasi dan Teknol. Inf., vol. 2, no. 1, pp. 103 108, 2019.

[3] M. Munawir, Z. Zulfan, Y. Yanti, and E. Erdiwansyah, "Perancangan Sistem Manajemen Administrasi Gampong Berbasis Aplikasi Desktop,” J. Serambi Eng., vol. 2, no. 4, 2017.

[4] Y. Yanti, M. Munawir, and Z. Zainal, "Implementasi Protocol Telnet Clientless Remote Deskstop Gateway,” J. Nas. Komputasi dan Teknol. Inf., vol. 2, no. 2, pp. 210-212, 2019.

[5] Y. Yanti, M. Munawir, Z. Zulfan, and E. Erdiwansyah, "Implementasi Sistem Keamanan Database Menggunakan Metode Triangle Chain,” J. Serambi Eng., vol. 2, no. 4, 2017.

[6] M. Munawir, S. Susmanto, Z. Zulfan, and T. Hidayat, "Perancangan Aplikasi Pengelolaan Surat pada Dinas Kependudukan Catatan Sipil Kabupaten Aceh Besar,” J. Serambi Eng., vol. 5, no. 3, 2020.

[7] D. Satria and T. Hidayat, "Implementation of wireless sensor network ( WSN ) on garbage transport warning information system using GSM module Implementation of wireless sensor network ( WSN ) on garbage transport warning information system using GSM module," 2019.

[8] Z. Zulfan, B. Bahagia, H. Ahmadian, and D. Satria, "Sistem Informasi Data Korban Kebencanaan Berbasis Web," in Prosiding Seminar Nasional USM, 2017, vol. 1, no. 1.

[9] B. G. Ginting and F. A. Sianturi, "Sistem Pendukung Keputusan Pemberian Bantuan Kepada Keluarga Kurang Mampu Menggunakan Metode AHP,” J. Nas. Komputasi dan Teknol. Inf., vol. 4, no. 1, 2021. 
[10] D. Satria, Z. Zainal, and T. Hidayat, "Plant Watering System Based on the Internet of Thing," J. Nas. Komputasi dan Teknol. Inf., vol. 1, no. 1, 2018.

[11] D. Satria, S. Yana, E. Yusibani, and S. Syahreza, "Implementation of the SMS Gateway in the Flood Early Warning Information System for Village Warning and Community Information,” no. 6, pp. 40054009, 2019.

[12] D. Satria, Z. Zulfan, M. Munawir, and D. Mulyati, "FINAL PROJECT CONSULTATION INFORMATION SYSTEM INTEGRATED NOTIFICATION SYSTEM BASED ON SMS GATEWAY," Cybersp. J. Pendidik. Teknol. Inf., vol. 2, no. 2, pp. 135-140, 2019.

[13] T. Zebua and E. Ndruru, "PENGAMANAN CITRA DIGITAL BERDASARKAN MODIFIKASI ALGORITMA RC4,” vol. 4, no. 4, pp. 275-282, 2017. 